\title{
Radiation therapy of carcinoma of the esophagus
}

THOMAS J KEANE, MB, MRCPI, FRCPC

\begin{abstract}
Radical radiation therapy with curative intent for esophageal squamous carcinoma is used both as a single modality and combined with chemotherapy. Failure to eradicate disease at the primary tumour site represents the greatest cause of failure of curative radiotherapy. The aim of curative radiotherapy is to deliver the highest dose of radiation at the tumour site while minimizing radiation delivered to the surrounding tissues. The best survival results are obtained in patients with tumours less than $5 \mathrm{~cm}$ in length, confined to the upper one-third of the esophagus. Regular endoscopic examinations two to three times per year in the first two years post treatment should rule out the vast majority of treatment failures. Can J Gastroenterol 1990;4(9):608-611
\end{abstract}

Key Words: Carcinoma of the esophagus, Radiation therapy

\section{Radiothérapie du cancer de l'oesophage}

RESUME: La radiothérapie radicale à visée curative est utilisée seule ou associée à la chimiothérapie dans le carcinome épidermoïde de l'oesophage. La nonéradication de la maladie au site de la tumeur primaire constitue la cause majeure d'échec thérapeutique. L'objectif de la radiothérapie curative est de délivrer la dose de radiation maximum au niveau de la localisation primaire sans léser les tissus environnants. Les meilleurs résultats de survie sont obtenus chez les patients dont les tumeurs sont d'un diamètre inférieur à $5 \mathrm{~cm}$ et limitées au premier tiers supérieur de l'oesophage. Des examens endoscopiques réguliers effectués deux ou trois fois par an dans les deux premières années qui suivent le traitement permettent de déceler la grande majorité des échecs thérapeutiques.

The Princess Margaret Hospital, Toronto, Ontario

Correspondence and reprints: Dr TJ Keane, The Princess Margaret Hospital, 500

Sherbourne Street, Toronto, Ontario M4X $1 K 9$
T IS NOW ALMOST 80 YEARS SINCE Gubez (1) reported on the use of radiation therapy in the management of carcinoma of the esophagus. This paper reviews the role of radical radia. tion therapy with curative intent both as a single modality and combined with chemotherapy. Unless indicated otherwise, only treatment of squamous carcinoma is discussed.

\section{TREATMENT WITH CURATIVE INTENT}

Radiation therapy shares with surgery a major limitation as a curative modality by virtue of being a nonsystemic therapy. It can, at best, only truly cure patients whose disease is localized within a volume amenable to a radical dose of radiation prior to the develop. ment of occult distant metastases. In practice, therefore, cure will only be possible in patients whose disease is lo. calized to the primary tumour site, and perhaps in a subset of patients with metastases limited to lymph nodes in adjacent tissues. The potential for cure 
TABLE 1

Sites of recurrence of squamous carcinoma of the esophagus

\begin{tabular}{lcccccc}
\hline Reference & $\begin{array}{c}\text { Number Radiotherapy } \\
\text { of patients }\end{array}$ & \multicolumn{2}{c}{$\begin{array}{c}\text { Recurrence (\%) } \\
\text { dose (rads) }\end{array}$} & $\begin{array}{c}\text { Distant } \\
\text { Local }\end{array}$ & $\begin{array}{c}\text { Margin } \\
\text { metastases }\end{array}$ \\
\hline Robertson et al (17) & 39 & $3000-7800$ & 56 & & & 36 \\
Elkon et al (18) & 30 & 6525 & $25^{*}$ & 25 & 10 & 25 \\
& & & $64^{\dagger}$ & 27 & 43 & 66 \\
Pierquin et al (19) & 115 & $4500-8000$ & 82 & & & 37 \\
Pearson (3) & 157 & 5000 & 61 & & & 23 \\
Beatty et al (20) & $176^{\S}$ & $4000-6000$ & 84 & & & 47 \\
\hline
\end{tabular}

Margin of treatment: "Stage I disease: ${ }^{\dagger}$ Stage II and III disease; ${ }^{4}$ Site causing death only: ${ }^{5}$ Includes 30 patients who had surgery and radiotherapy. (Reprinted from Cancer Treat Symp 1983;2:87)

\section{TABLE 2}

Radiation tolerance dose and clinical sequelae for normal tissues

\begin{tabular}{|c|c|c|c|}
\hline $\begin{array}{l}\text { Clinically normal } \\
\text { tissue }\end{array}$ & Clinical manifestation & TD $5 / 5^{*}$ & $\begin{array}{l}\text { Usual time of } \\
\text { onset }\end{array}$ \\
\hline Spinal cord & $\begin{array}{l}\text { Transverse myelitis, } \\
\text { Brown-Sequard syndrome }\end{array}$ & $45 \mathrm{~Gy}$ & 6-36 months \\
\hline $\begin{array}{l}\text { Heart } \\
\qquad(60 \% \text { volume })\end{array}$ & $\begin{array}{l}\text { Pericardial effusion, } \\
\text { constrictive pericarditis }\end{array}$ & $45 \mathrm{~Gy}$ & $12-60$ months \\
\hline Lung (single) & Acute pneumonitis & $15 \mathrm{~Gy}^{\dagger}$ & $2-6$ months \\
\hline $\begin{array}{l}\text { Stomach } \\
\text { (entire organ) }\end{array}$ & $\begin{array}{l}\text { Ulceration, fibrosis, } \\
\text { bleeding }\end{array}$ & $45 \mathrm{~Gy}$ & 6-12 months \\
\hline
\end{tabular}

Dose estimates are approximate for fractions of 2 Gy/day, five days per week. "5\% risk within five years: 'Uncorrected for heterogeneity

among this latter group is not available in the radiation therapy literature, as stagirig is clinical and the status of mediastinal nodes has not usually been stated. However, if information in the surgical literature is a valid comparison, then the work of Skinner and his colleagues (2) is not encouraging. For all carcinomas in their series, only two of 17 patients survived, even when lymph node metastases were confined to one or two nodes. The proportion of patients in radiotherapy series who are judged suitable for potentially curative treatment based on clinical staging varies from a high of $63 \%$ when radiotherapy was virtually the only approach to radical treatment (3) to a much lower proportion of $19 \%$ for curative radiotherapy alone (4). The degree of selection and the criteria used for such treatment decision making must be known before any judgement can be made as to the value of any radical treatment approach. It is probably fair to say that many claims for improved treatment represent triumphs of selection rather than triumphs of treatment per se.

It can be seen from Table 1 that failure to eradicate disease at the primary tumour site represents the greatest cause of failure of therapy, and any improvement in cure rates must start with improvements in control of the primary tumour. It should be remembered that not all patients whose primary tumours are controlled will survive, as many will succumb to distant metastases by virtue of living long enough for such metastases to become apparent.

\section{RADIATION TREATMENT PLANNING}

The aim of curative radiotherapy for carcinoma of the esophagus is to deliver the highest dose of radiation to the site of the tumour while minimizing radiation delivered to the surrounding normal tissues. The obvious expectation is to maximize local tumour control while minimizing complications to normal tissues. The critical tissues are the esophagus itself, the lung, the heart, and perhaps of most concern, the spinal cord. The radiation tolerance of these organs varies considerably, as does the functional tolerance of the organs themselves. The latter concept depends on the volume of the organ which must be radiated at a given dose to produce a clinical complication. For example, the radiation tolerance of a small volume of lung can be exceeded without clinical consequence, whereas exceeding the radiation tolerance of any length of the spinal cord will always result in serious neurological sequelae. Table 2 outlines the tolerance dose and clinical sequelae for some relevant normal tissues.

External beam therapy: Figure 1 shows a typical computed tomography-assisted treatment plan. By arranging a combination of anterior posterior fields followed by one anterior and two posterior oblique fields, the distribution of radiation dose is kept within the tolerance of critical structures. A beam energy of 8 to $10 \mathrm{MeV}$ is used in this example. At energies of 8 to $10 \mathrm{MeV}$ or greater, dose distributions similar to those shown in Figure 1 can usually be obtained irrespective of the anatomical size of the patient.

Intraluminal therapy: Recent improvements in dose delivery systems for intraluminal therapy have revived interest in this form of treatment. Because of the physics of dose gradients from line sources, this form of treatment can only be used alone as curative treatment for very superficial lesions which are rarely encountered in North American patient populations. When combined with external beam therapy to deliver a curative dose to the primary tumour, it offers the best hope of improving the therapeutic ratio for radiation treatment. The largest series employing this technique as a boost combined with external beam therapy by Flores et al (5) reports a 26\% survival at two years for a series of 171 patients, of whom 145 received no treatment other than radiation.

\section{SURVIVAL FOLLOWING RADICAL RADIOTHERAPY ALONE}

The results of treatment are heavily dependent on the degree of selection for any particular therapy. Particular attention should be paid to the total number of patients receiving radical treatment as a proportion of all patients 


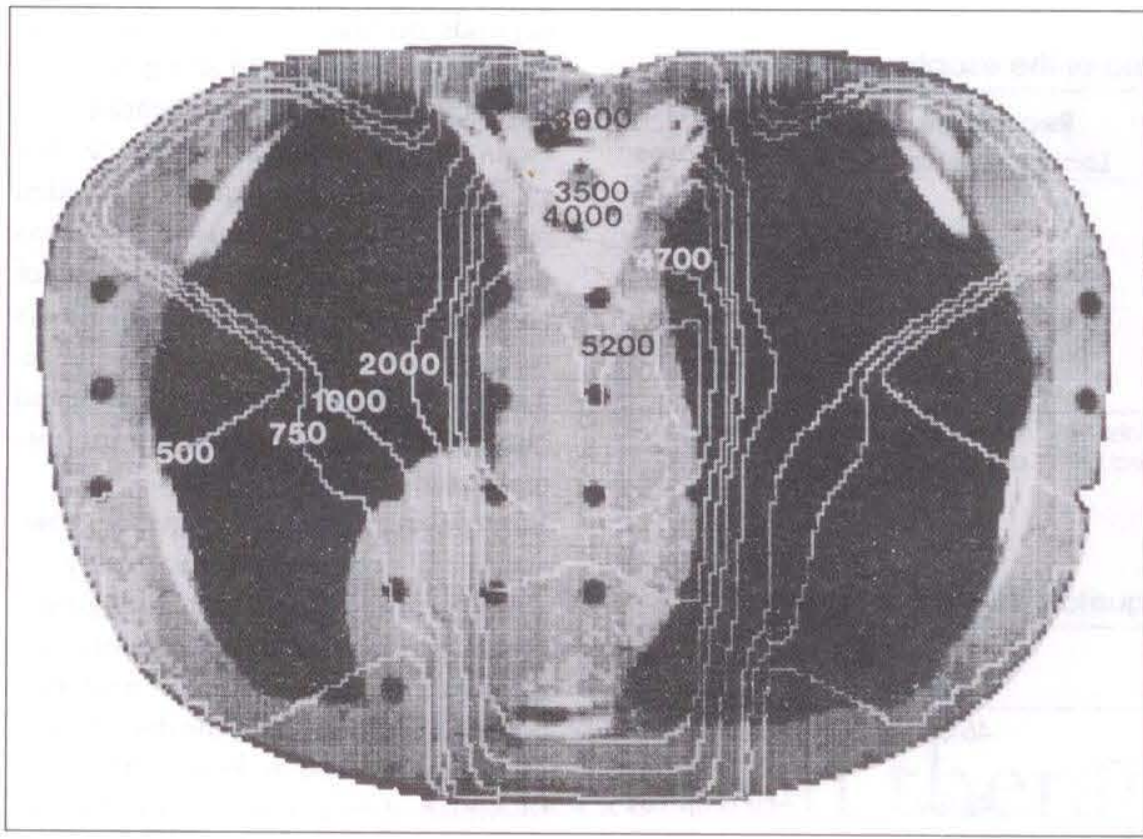

Figure 1) Typical computed tomography isodose distribution at the central axis for a combined five field technique using $18 \mathrm{MeV}$ photons with dose correction for lung heterogeneity

\section{TABLE 3}

Squamous cell carcinoma of the esophagus radiotherapy-chemotherapy studies

\begin{tabular}{|c|c|c|c|}
\hline Study/reference & $\begin{array}{c}\text { No. of } \\
\text { patients }\end{array}$ & $\begin{array}{l}\text { Median } \\
\text { survival }\end{array}$ & $\begin{array}{c}\text { Radiotherapy } \\
\text { dose }\end{array}$ \\
\hline $\begin{array}{l}\text { Radiotherapy + bleomycin versus } \\
\text { radiotherapy (randomized) } \\
\text { Earle et al } 1980 \text { (9) }\end{array}$ & $\begin{array}{l}40 \\
37\end{array}$ & $\begin{array}{l}6.4 \text { weeks } \\
6.2 \text { months }\end{array}$ & $\begin{array}{l}50-60 \text { Gy in } \\
5 \text { to } 6 \text { weeks }\end{array}$ \\
\hline $\begin{array}{l}\text { Radiotherapy }+ \text { methotrexate versus } \\
\text { radiotherapy } \\
\text { Roussel et al } 1988 \text { (15) }\end{array}$ & $\begin{array}{l}72 \\
70\end{array}$ & $\begin{array}{l}9 \text { months } \\
8 \text { months }\end{array}$ & $\begin{array}{l}56.25 \text { Gy in } \\
5 \text { weeks }\end{array}$ \\
\hline $\begin{array}{l}\text { Radiotherapy + DDP + } 5 \mathrm{FU}+\text { mitomycin C } \\
\quad+\text { bleomycin } \\
\text { Leichman et al } 1985 \text { (13) }\end{array}$ & 20 & 22 months & $\begin{array}{l}50 \text { Gy in } \\
15 \text { weeks }\end{array}$ \\
\hline $\begin{array}{l}\text { Radiotherapy + mitomycin C + 5FU } \\
\text { Keane et al } 1985 \text { (11) }\end{array}$ & 35 & 12 months & $\begin{array}{l}45-50 \text { Gy in } \\
4 \text { to } 8 \text { weeks }\end{array}$ \\
\hline $\begin{array}{l}\text { Radiotherapy + mitomycin C + 5FU } \\
\text { Chan et al } 1989 \text { (12) }\end{array}$ & 21 & 13 months & $\begin{array}{l}45-50 \text { Gy in } \\
8 \text { weeks }\end{array}$ \\
\hline $\begin{array}{l}\text { Radiotherapy }+5 \mathrm{FU} \\
\text { Byfield et al } 1979(16)\end{array}$ & 6 & 22 months & $\begin{array}{l}60 \text { Gy in } \\
12 \text { weeks }\end{array}$ \\
\hline
\end{tabular}

DDP Cis-platinum; FU Fluorouracil

in any series, and the extent to which surgery and radiation therapy are applied as curative treatment within any centre. The best results show a $17 \%$ five year survival rate for a subset of 248 patients representing $40 \%$ of all cases treated with curative intent over an 18 year period in Edinburgh, Scotland (6). The degree to which this series represents selection can be inferred by the fact that the overall five year survival for all patients was between 7 and 9\% for the entire period. A further analysis of data from Edinburgh for an overlapping time period was carried out by Newaishey and colleagues (7). When the definition of curative intent was inferred only by the prescription of radical dose, the five year survival rate among 444 of 848 patients so defined was $9 \%$. This figure is within one standard deviation of the mean $6 \%$ five year survival rate derived by Earlam and Cunha-Melo (8) from 49 papers and a total of 8489 patients following esophageal cancer radiotherapy.

\section{PROGNOSTIC FACTORS}

There are a number of prognostic fac tors which appear to be advantageous in terms of survival following radical radia tion therapy. Improved survival for female patients has been reported in several series. Newaishey and associates (7) reported a $5.67 \%$ five year crude sur vival for males compared to $11.6 \%$ for females. A comparison of survival patterns suggested that this difference only reached statistical significance after five years of follow-up. This survival difference was only demonstrated for tumours greater than $5 \mathrm{~cm}$ in length.

Tumour location has been considered important in several series with a general trend towards improved survival for lesions in the cervical and up. per one-third of the esophagus. Other prognostic factors are disputed and may reflect difficuities with univariate analysis and small numbers of patients. Based on the available evidence it would appear reasonable to suggest that the best survival results with radical radiation therapy are obtained in patients with tumours less than $5 \mathrm{~cm}$ in length, confined to the upper one-third of the esophagus.

\section{CHEMOTHERAPY AS AN ADJUVANT TO CURATIVE RADIOTHERAPY}

Much of the recent interest in chemotherapy/radiotherapy combinations has centred on concurrent administration of chemotherapy with radiation. In general the administration of drugs is usually limited to one or two courses during or very close to the time of radiotherapy. While the rationale is not often stated, the general intent ap. pears to be to improve radiation effect on the primary tumour rather than influencing systemic disease. Presently, the scientific basis for any advanta. geous drug radiotherapy interaction temains unclear, but possibilities range from simple additivity of effect to true sensitization. To date only bleomycin (9) and methotrexate (10) have been studied in a prospective randomized manner and have not shown a benefit. There are now several reports of encouraging nonrandomized studies of combinations of 5 -fluorouracil infusion 
with either mitomycin $\mathrm{C}(11,12)$ or cisplatin (13). The results of randomized studies of these combinations being conducted by the Eastern Cooperative Oncology Group (ECOG) and the Radiation Therapy Oncology Group (RTOG) are still awaited. A summary of the bleomycin and methotrexate randomized trials and the phase II studies of mitomycin $\mathrm{C} / 5 \mathrm{FU}$ and cisplatin $/ 5 \mathrm{FU}$ is shown in Table 3 .

\section{POST RADIOTHERAPY MANAGEMENT}

The vast majority of local treatment failures appear within the first 18 months after radical dose radiotherapy. It is important to distinguish persistent or recurrent tumours from post radio-

\section{REFERENCES}

1. Guisez J. Essais de traitement de quelque cas d'épithelioma de l'oesophage par les applications locales directes de redium. Bull Soc Med Hop Paris 1909;27:717.

2. Skinner DB, Dowiatshahi KD, DeMeester TR. Potentially curable cancer of the oesophagus. Cancer 1987.50:2571.

3. Pearson JG. The value of radiotherapy in the management of esophageal cancer. Am J Roentgenol 1969;105:500-13.

4. Barkley HT, Hussey DH, Saxton JP, Spanso WJ. Radiotherapy in the treatment of carcinoma of the oesophagus. In: Stroehlein JR, Remsdahl NM, eds. Gastrointestinal Cancer. New York: Raven Press, 1981:171.

5. Flores AD, Nelems B, Evans K, Hay J, Stoller J, Jackson S. Impact of new radiotherapy modalities on the surgical management of cancer of the esophagus and cardia. Int J Radiat Oncol Biol Phys 1989;17:937-44.

6. Pearson JG. The present status and future potential for radiotherapy in the management of esophageal cancer. Cancer 1977;39:882.

7. Newaishey GA, Read GA, Duncan W. Results of radical radiotherapy of the squamous carcinoma of the esophagus. Clin Radiol 1982;33:347.

8. Earlam R, Cunha-Melo JR. Esophageal squamous cell carcinoma II. A critical therapy strictures. For this reason regular endoscopic examinations two to three times per year in the first two years post treatment are required. In addition, dilation of any strictures before they cause serious esophageal obstruction is recommended. Biopsy and/or brushing of strictures should be performed whenever doubt exists as to the cause of stricture formation. It should not be assumed that stricture formation and/or ulceration following radiotherapy is a clue to tumour recurrence, despite the likelihood that this may be the case. Histological proof of treatment failure is essential for decision making regarding the choice of the most appropriate subsequent treatment by whatever modality. It is

review of radiotherapy. $\mathrm{Br}]$ Surg 1980;67:457.

9. Earle J, Gelber R, Moertel C. A controlled evaluation of combined radiation and bleomycin therapy for squamous cell carcinoma of the esophagus. Int J Radiat Oncol Biol Phys 1980;6:821.

10. Gerard A, Gignoux M, Roussel A, et al. Prospective and controlled studies on multidisciplinary treatment of gastrointestinal cancer. In: Klein HO, ed. Recent Results in Cancer Research. Heidelberg: Springer-Verlag, 1981:79.

11. Keane T], Harwood AR, Elhakim T, et al. Radical radiation therapy with 5 . fluoro-uracil infusion and mitomycin C for esophageal squamous cell carcinoma. Radiat Oncol 1985:4:205.

12. Chan A, Wong A, Arthur K. Concomitant 5 -fluorouracil infusion, mitomycin $\mathrm{C}$ and radical radiation therapy in esophageal squamous cell carcinoma. Int J Radiat Oncol Biol Phys 1989;16:59-65.

13. Leichman I, Herskovic A, Leichman $\mathrm{CG}$, et al. Non-operative therapy for squamous cell cancer of the esophagus. J Clin Oncol 1987;5:365.

14. Aisner J, Forastiere A, Aroney R. Patterns of recurrence for carcinoma of the lung and oesophagus. Cancer Treat Symp 1983;2:87.

15. Roussell A, Jacob H, Haegele P, et al. A controlled trial for the treatment of rarely possible to offer curative surgical treatment to patients who fail initial radiation therapy, even in highly selected cases. The operative mortality in such situations may also be unacceptable given the potential benefit.

\section{CONCLUSIONS}

Primary treatment failure remains the greatest current challenge in the use of radical radiotherapy for esophageal squamous carcinoma. Careful selection of cases is necessary to identify the approximately 10 to $15 \%$ of patients who may be amenable to long term cure. Treatment following local radiotherapy failure is rarely curative and is probably best considered from a palliative perspective.

patients with inoperable esophageal carcinoma. A study of the EORTC Gastrointestinal Tract Cancer Cooperative Group, In: Schlag P, Hochenberger P, Metzger U, eds. Recent Results in Cancer Research, Vol 110. Heidelberg: Springer-Verlag, 1988.

16. Byfield J, Barone R, Mendelsohn J, et al. Infusional $5 \mathrm{FU}$ and radiation therapy for nonresectable esophageal carcinoma. Cancer 1980;45:703-8.

17. Robertson R, Coy P, Mokkhavesa S. The results of radical surgery compared with radical radiotherapy in the treatment of squamous carcinoma of the thoracic esophagus. J Thorac Cardiovase Surg 1967;53:430-40.

18. Elkon D, Myung-Sook L, Hendrickson FR. Carcinoma of the esophagus: Sites of recurrence and palliative benefits after definitive radiotherapy. Int J Radiat Oncol Biol Phys 1978;4:615.

19. Pierquin B, Wambersie A, Tubiana $M$. Cancer of the thoracic esophagus: Two series of patients treated by 22 $\mathrm{MeV}$ betatron. $\mathrm{Br} J$ Radiol 1966;39:189-92.

20. Beatty JD, DeBoer G, Rider WD. Carcinoma of the esophagus: Pretreatment assessment, correlation of radiation treatment parameters with survival, and identification and management of radiation treatment failure. Cancer 1979;43:2254-67. 


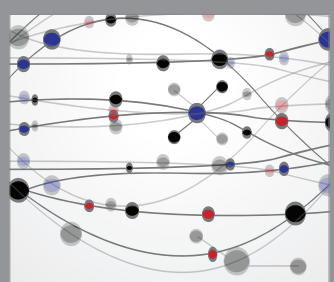

The Scientific World Journal
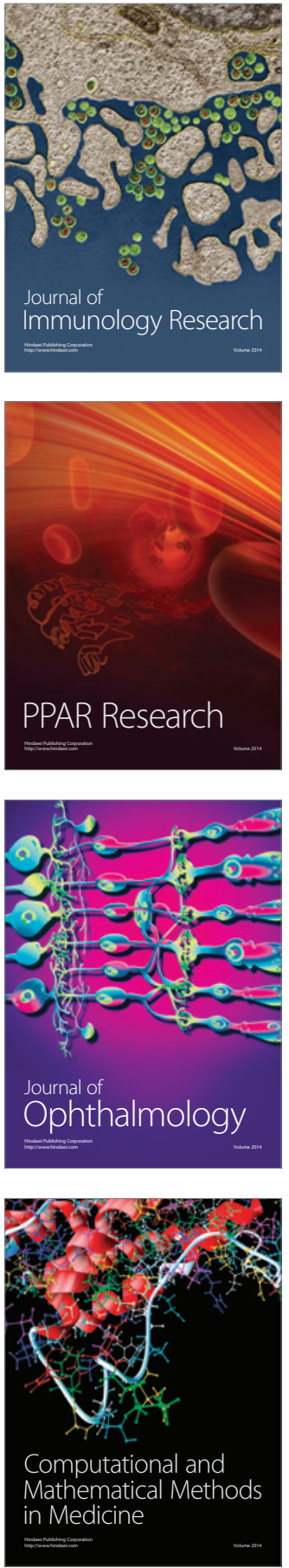

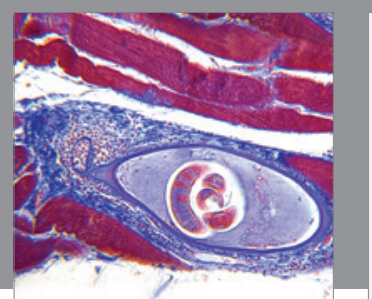

Gastroenterology Research and Practice

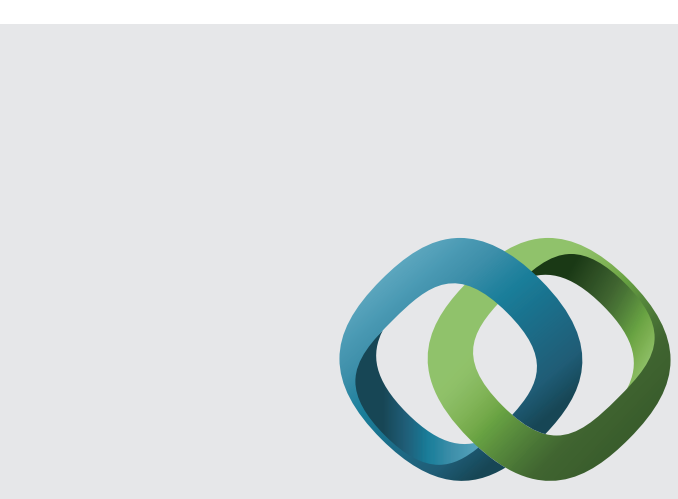

\section{Hindawi}

Submit your manuscripts at

http://www.hindawi.com
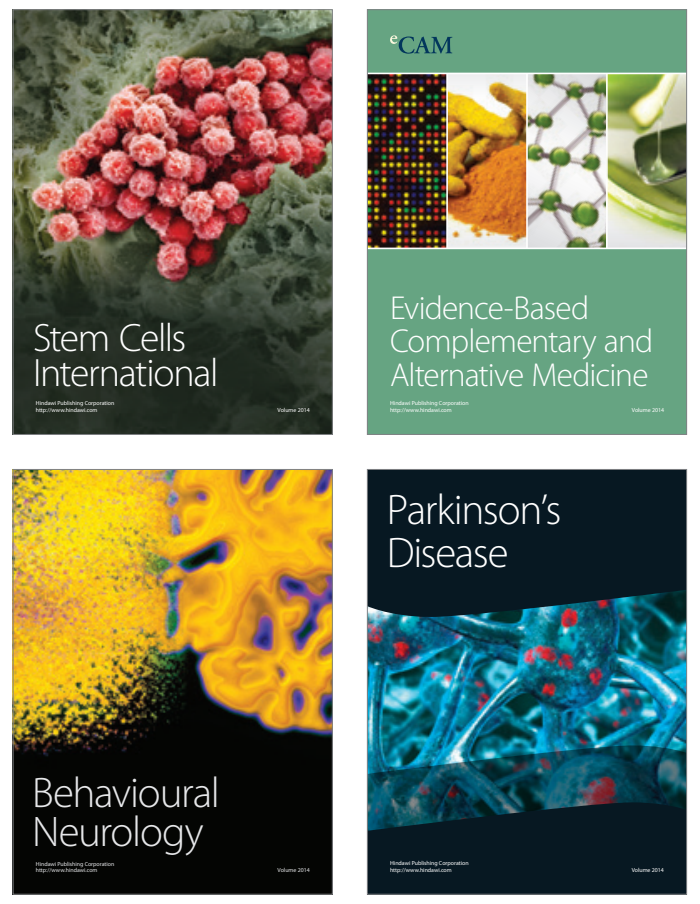
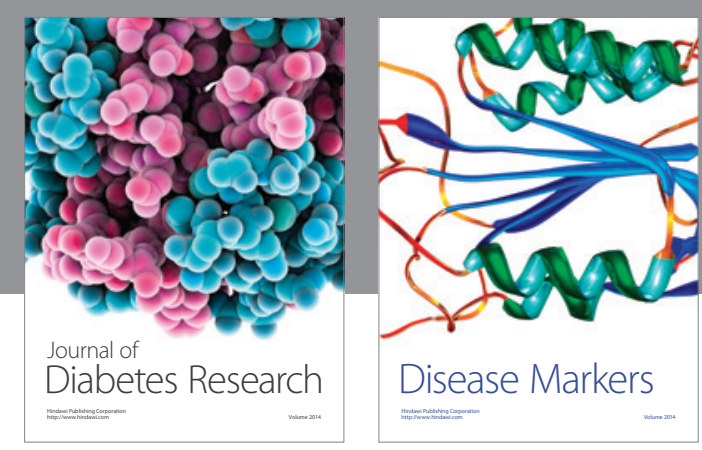

Disease Markers
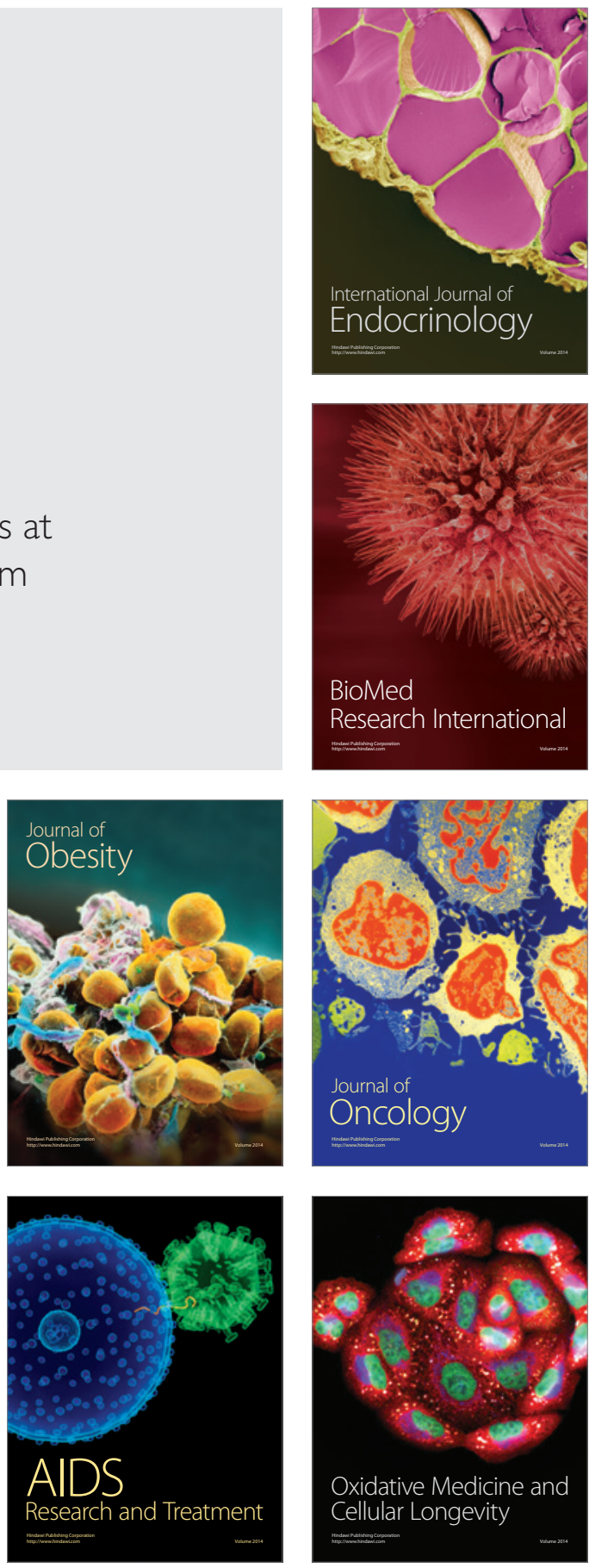